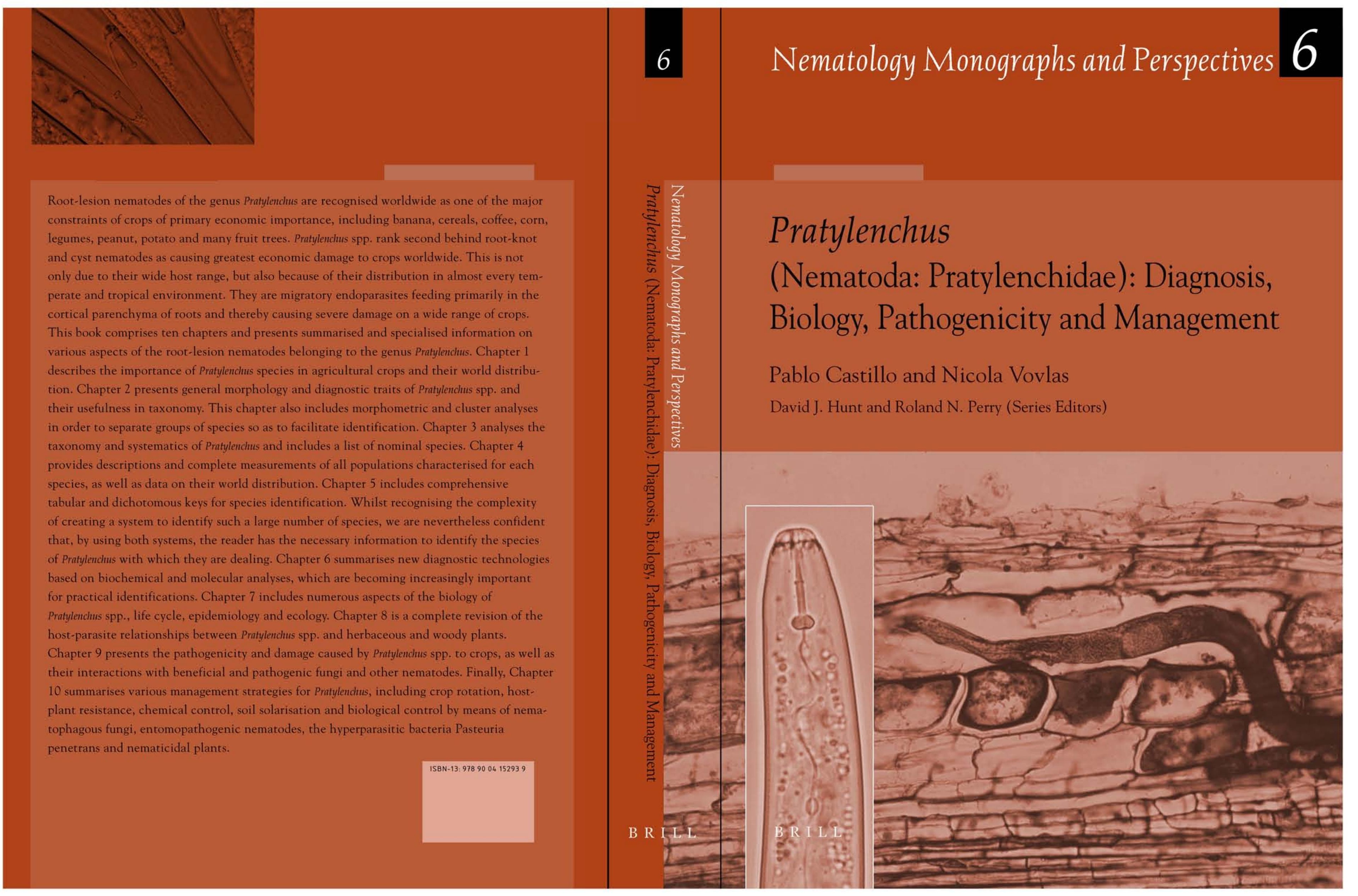


PRATYLENCHUS (NEMATODA:

PRATYLENCHIDAE): DIAGNOSIS, BIOLOGY, PATHOGENICITY AND MANAGEMENT 


\title{
PRATYLENCHUS (NEMATODA: PRATYLENCHIDAE): DIAGNOSIS, BIOLOGY, PATHOGENICITY AND MANAGEMENT
}

\author{
Pablo Castillo and Nicola Vovlas \\ David J. Hunt and Roland N. Perry (Series Editors)
}

NEMATOLOGY MONOGRAPHS AND PERSPECTIVES

VOLUME 6

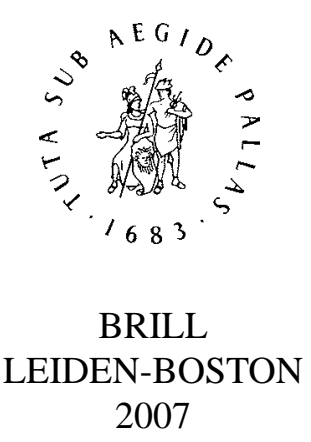


This book is printed on acid-free paper.

\section{Library of Congress Cataloging-in-Publication Data}

The Library of Congress Cataloging-in-Publication Data is available from the Publisher.

Cover illustration: The cereal and legume root-lesion nematode Pratylenchus thornei migrating into the cortical parenchyma of chickpea roots.

ISBN-10: 9004155643

ISBN-13: 9789004155640

(C) Copyright 2007 by Koninklijke Brill NV, Leiden, The Netherlands. Koninklijke Brill NV incorporates the imprints Brill Academic Publishers, Martinus Nijhoff Publishers and VSP.

All rights reserved. No part of this publication may be reproduced, translated, stored in a retrieval system, or transmitted in any form or by any means, electronic, mechanical, photocopying, recording or otherwise, without written permission of the publisher.

Authorization to photocopy items for internal or personal use is granted by Brill provided that the appropriate fees are paid directly to Copyright Clearance Center, 222 Rosewood Drive, Suite 910, Danvers, MA 01923, USA. Fees are subject to change. 


\section{Dedication}

The authors dedicate this book to our parents, José $M^{a}$ and Gregoria and Athanasio and Polixena, as a way to express our innermost gratitude for their efforts and sacrifices during their lives and the permanent support they demonstrated for us. 


\section{Contents}

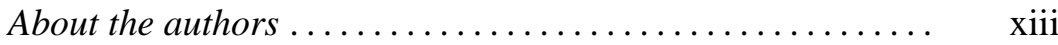

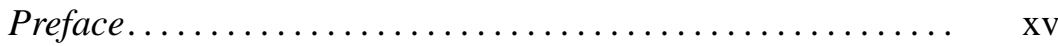

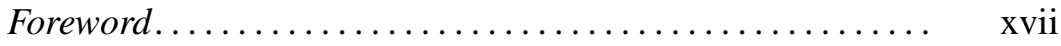

Acknowledgements...................... xix

1. Introduction ............................ 1-7

Geographical distribution of Pratylenchus ........... 5

2. Morphology of Pratylenchus species............ 9-36

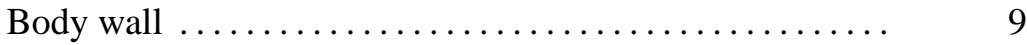

Body length and shape $\ldots \ldots \ldots \ldots \ldots \ldots \ldots \ldots \ldots \ldots . \ldots \ldots$

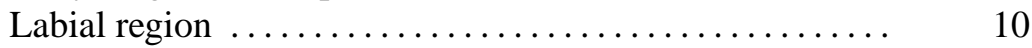

Lateral fields $\ldots \ldots \ldots \ldots \ldots \ldots \ldots \ldots \ldots \ldots \ldots \ldots \ldots \ldots$

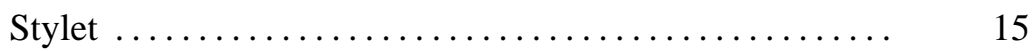

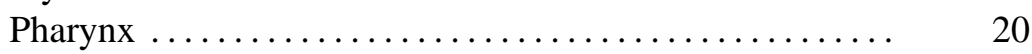

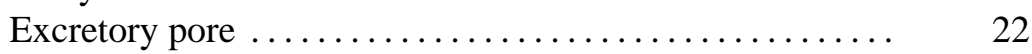

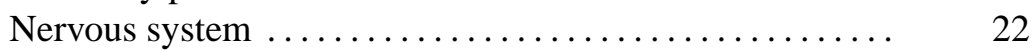

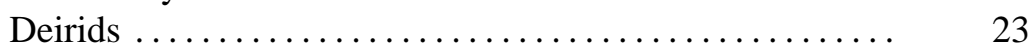

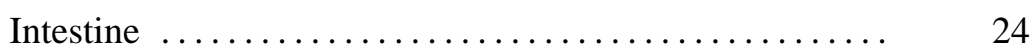

Reproductive system .................... 24

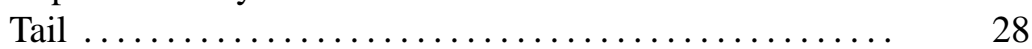

Morphometrics and cluster analysis $\ldots \ldots \ldots \ldots \ldots \ldots$.

3. Taxonomy and systematics ............... 37-50

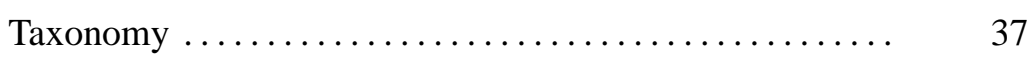

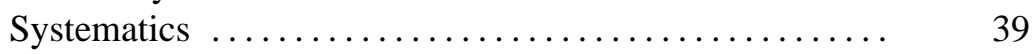

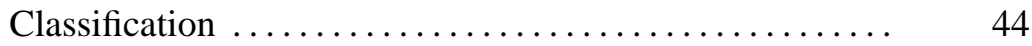

4. Diagnosis and descriptions of Pratylenchus species. . $\quad$ 51-280

1. Pratylenchus pratensis (de Man, 1880) Filipjev,

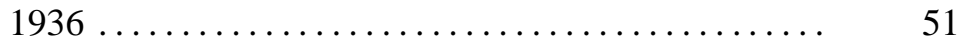

2. Pratylenchus acuticaudatus Braasch \& Decker, 1989 . 55

3. Pratylenchus alleni Ferris, 1961 ............. 57

4. Pratylenchus andinus Lordello, Zamith \& Boock,
$1961 \ldots \ldots \ldots \ldots \ldots \ldots \ldots \ldots \ldots \ldots \ldots \ldots \ldots \ldots \ldots \ldots \ldots \ldots \ldots$

5. Pratylenchus angulatus Siddiqi, $1994 \ldots \ldots \ldots \ldots \ldots 62$

(C) Koninklijke Brill NV, Leiden, $2007 \quad$ vii 
6. Pratylenchus arlingtoni Handoo, Carta \& Skantar,

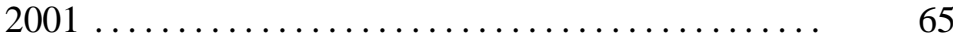

7. Pratylenchus artemisiae Zheng \& Chen, 1994 ..... $\quad 69$

8. Pratylenchus bhattii Siddiqi, Dabur \& Bajaj, 1991 ... 71

9. Pratylenchus bolivianus Corbett, 1983 ............ 74

10. Pratylenchus brachyurus (Godfrey, 1929) Filipjev \& Schuurmans Stekhoven, 1941 ................ $\quad 77$

11. Pratylenchus brzeskii Karssen, Waeyenberge \& Moens, $2000 \ldots \ldots \ldots \ldots \ldots \ldots \ldots \ldots \ldots \ldots . \ldots \ldots . \ldots . \ldots 1$

12. Pratylenchus coffeae (Zimmermann, 1898) Filipjev \& Schuurmans Stekhoven, $1941 \ldots \ldots \ldots \ldots \ldots \ldots . . \ldots 5$

13. Pratylenchus convallariae Seinhorst, 1959 ........ 91

14. Pratylenchus crassi Das \& Sultana, 1979 ......... 94

15. Pratylenchus crenatus Loof, 1960 ............... 96

16. Pratylenchus cruciferus Bajaj \& Bhatti, 1984 ....... $\quad 100$

17. Pratylenchus curvicauda Siddiqi, Dabur \& Bajaj, 1991 ....................................... 102

18. Pratylenchus delattrei Luc, 1958 ................ 105

19. Pratylenchus dunensis de la Peña, Moens, van Aelst \&

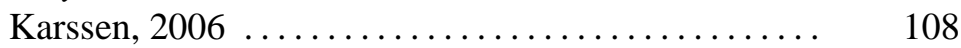

20. Pratylenchus ekrami Bajaj \& Bhatti, 1984 ........ 112

21. Pratylenchus elamini Zeidan \& Geraert, 1991 ...... 115

22. Pratylenchus estoniensis Ryss, 1982 ............ 117

23. Pratylenchus fallax Seinhorst, 1968 ............ 120

24. Pratylenchus flakkensis Seinhorst, 1968 .......... 123

25. Pratylenchus gibbicaudatus Minagawa, 1982 ....... 126

26. Pratylenchus goodeyi Sher \& Allen, 1953 ......... 129

27. Pratylenchus hexincisus Taylor \& Jenkins, 1957 .... 132

28. Pratylenchus hippeastri Inserra, Troccoli, Gozel,
Bernard, Dunn \& Duncan, 2007 ............... 136

29. Pratylenchus jaehni Inserra, Duncan, Troccoli, Dunn,
dos Santos, Kaplan \& Vovlas, 2001 ............. 140

30. Pratylenchus japonicus Ryss, 1988 .............. 144

31. Pratylenchus kasari Ryss, 1982 ................ 149

32. Pratylenchus kralli Ryss, 1982 ................ 151

33. Pratylenchus kumaoensis Lal \& Khan, 1990 ....... 154

34. Pratylenchus loosi Loof, 1960 ................ 156

35. Pratylenchus macrostylus $\mathrm{Wu}, 1971 \ldots \ldots \ldots \ldots . .159$ 
36. Pratylenchus manaliensis Khan \& Sharma, $1992 \ldots . \quad 162$

37. Pratylenchus mediterraneus Corbett, 1983 ........ 165

38. Pratylenchus microstylus Bajaj \& Bhatti, 1984 ..... 168

39. Pratylenchus morettoi Luc, Baldwin \& Bell, 1986 ... 170

40. Pratylenchus mulchandi Nandakumar \& Khera, 1970

41. Pratylenchus neglectus (Rensch, 1924) Filipjev \&

Schuurmans Stekhoven, 1941 ................. 177

42. Pratylenchus neobrachyurus Siddiqi, 1994 ........ 184

43. Pratylenchus okinawaensis Minagawa, 1991 ...... 187

44. Pratylenchus panamaensis Siddiqi, Dabur \& Bajaj, 1991

45. Pratylenchus penetrans (Cobb, 1917) Filipjev \&

Schuurmans Stekhoven, 1941 .................. 194

46. Pratylenchus pinguicaudatus Corbett, 1969 ........ 200

47. Pratylenchus pratensisobrinus Bernard, 1984 ....... 203

48. Pratylenchus pseudocoffeae Mizukubo, 1992 ....... 206

49. Pratylenchus pseudofallax Café-Filho \& Huang,

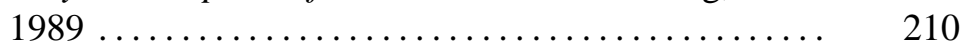

50. Pratylenchus pseudopratensis Seinhorst, 1968 ...... 214

51. Pratylenchus roseus Zarina \& Maqbool, 1998 ...... 217

52. Pratylenchus scribneri Steiner in Sherbakoff \& Stanley, 1943 ........................... 219

53. Pratylenchus sensillatus Anderson \& Townshend,
$1985 \ldots \ldots \ldots \ldots \ldots \ldots \ldots \ldots \ldots \ldots \ldots \ldots \ldots \ldots \ldots \ldots \ldots . \ldots \ldots$

54. Pratylenchus silvaticus Brzeski, 1998 .............. 229

55. Pratylenchus subpenetrans Taylor \& Jenkins, 1957 .. 231

56. Pratylenchus subranjani Mizukubo, Toida, Keereewan
\& Yoshida, 1990 ............................ 234

57. Pratylenchus sudanensis Loof \& Yassin, $1971 \ldots \ldots . \quad 238$

58. Pratylenchus tenuis Thorne \& Malek, 1968 ....... 241

59. Pratylenchus teres Khan \& Singh, $1974 \ldots \ldots \ldots \ldots . \quad 243$

60. Pratylenchus thornei Sher \& Allen, 1953 ......... 247

61. Pratylenchus typicus Rashid, 1974 ............. 253

62. Pratylenchus unzenensis Mizukubo, 1992 ......... 256

63. Pratylenchus ventroprojectus Bernard, 1984 ....... 259

64. Pratylenchus vulnus Allen \& Jensen, 1951 ........ 262

65. Pratylenchus wescolagricus Corbett, 1983 ....... 267 
66. Pratylenchus yamagutii Minagawa, 1991 ......... 270

67. Pratylenchus yassini Zeidan \& Geraert, 1991 ....... 273

68. Pratylenchus zeae Graham, 1951 .............. 275

5. Specific diagnostic differentiation............. $281-293$

Morphological characters used to distinguish Pratylenchus spp. in tabular and dichotomous keys ........... 282

Tabular key for the identification of Pratylenchus spp. ... 285

Dichotomous key for the identification of Pratylenchus spp. ..................................... 289

Key to species of Pratylenchus ................. 289

6. Biochemical and molecular approaches in Pratylenchus diagnosis ................................ $295 \mathbf{2 9 3}$

Biochemical identification ....................... 295

Molecular identification ........................... . 297

7. Biology and ecology of Pratylenchus ........... $\quad 305-324$

Biology ............................... 305

Embryogenesis and post-embryogenesis ......... 305

Life cycle ........................... 308

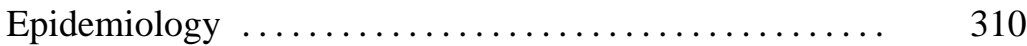

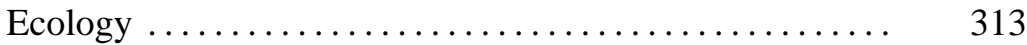

Soil texture ............................. 313

Soil temperature .......................... 314

Soil moisture .......................... 315

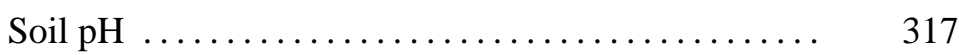

Seasonal fluctuations ......................... $\quad 318$

Vertical distribution .......................... $\quad 319$

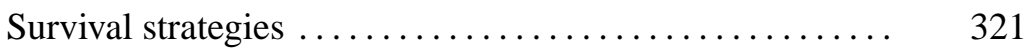

8. Pathogenicity of Pratylenchus species ........... $\quad 325-354$

Pathogenic variability in Pratylenchus .............. 328

Host range ............................. 331

Damage thresholds of Pratylenchus spp. ............ 334

Damage to herbaceous and vegetable crops .......... 337

Damage to fruit trees and woody plants $\ldots . \ldots \ldots \ldots \ldots . \quad 343$

Interactions of Pratylenchus spp. with other plant-parasitic nematodes .......................... 346

Interactions of Pratylenchus spp. with bacteria ....... 348 
9. Host-parasite relationships of Pratylenchus species on crops ................................. $\quad 355-363$

Feeding behaviour and mechanism of pathogenesis ..... 355

10. Management strategies of Pratylenchus species... 365-407

Pratylenchus spp. in propagating plant material ....... 366

Crop rotation and cultural practices $\ldots \ldots \ldots \ldots \ldots \ldots . \quad 368$

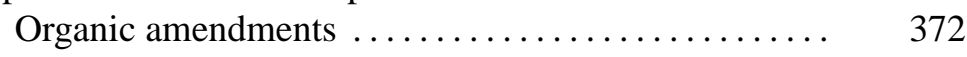

Cover crops . ........................... 374

Nematicidal plants ...................... $\quad 376$

Physical control ............................ 380

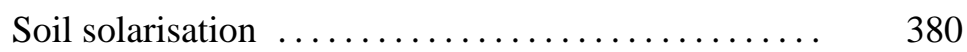

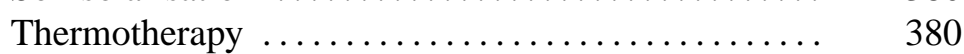

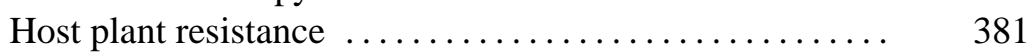

Fruit trees and woody plants $\ldots \ldots \ldots \ldots \ldots \ldots \ldots . \ldots \ldots 2$

Roses .................................. $\quad 384$

Potato and sweet potato .................... $\quad 384$

Strawberries and raspberries $\ldots \ldots \ldots \ldots \ldots \ldots . . \ldots . \ldots 385$

Cereals and legumes ..................... $\quad 386$

Banana ................................. 389

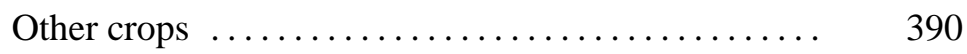

Mechanisms of resistance ................... 391

Biological control ......................... 392

Bacteria and beneficial endophytic microorganisms . 393

Nematophagous fungi .................... 395

Entomopathogenic nematodes ................ 396

Predaceous nematodes ..................... 396

Pasteuria penetrans ....................... 396

Arbuscular mycorrhizal fungi ................ $\quad 397$

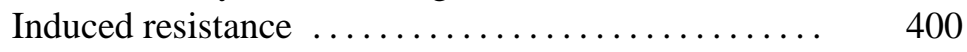

Chemical control .......................... 400

Herbaceous and vegetable crops .............. 401

Fruit trees and woody plants $\ldots \ldots \ldots \ldots \ldots \ldots \ldots . \ldots \ldots \ldots$

Novel nematicide compounds ............... 406

Herbicides .......................... 407

Appendix................................ $\quad 409-414$

List of abbreviations ....................... $\quad 415-415$

Vol. 6, $2007 \quad$ xi 


\section{Contents}

References............................ 417-522

Subject index........................ 523-529 


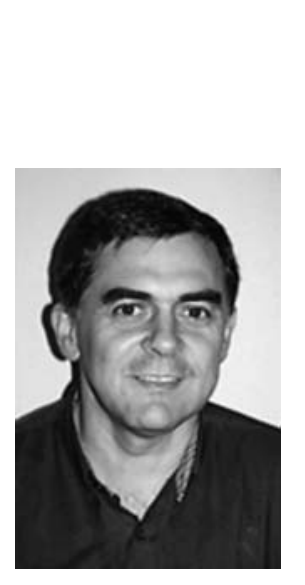

Pablo Castillo was born in Castillo de Locubín, province of Jaén, southern Spain, in June 1960. He received his B.Sc. in Biology at the University of Granada, Spain, in June 1984 and his Ph.D. in Nematology at the University of Granada in December 1988. He joined the Department of Crop Protection at the Centre for Agricultural Research and Formation in Granada from the regional government of Andalusia in 1989. In 1990 he was recipient of the Phytopathological Research Award 'Antonio Ciccarone', from the Mediterranean Phytopathological Union, and in 1992 moved to Córdoba (Spain) to the Department of Crop Protection at the Institute of Sustainable Agriculture belonging to the Spanish Council for Scientific Research, where he is now a research scientist.

Castillo's research has focused primarily on plant-nematode and nematode-soilborne fungi interactions, as well as diagnosis of nematode diseases, host-parasite relationships and nematode control by means of strategies compatible with sustainable agriculture. He has produced more than 65 peerreviewed research articles and recently coauthored a comprehensive monograph of the plant-parasitic nematode genus Rotylenchus.

\section{About the authors}

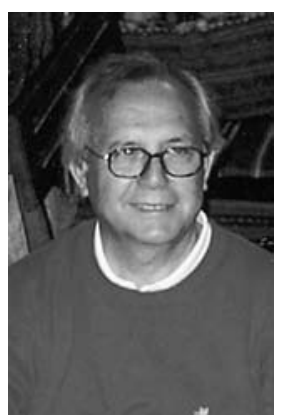

Nicola Vovlas was born in Distraton-Arta, Greece, in October, 1944. He received his university degree in Agricultural Sciences in Italy from the University of Naples in 1968 . From 1977 to 1991 he held the position of researcher at the Istituto di Nematologia Agraria di Bari where he currently serves as a research leader. His research interests include nematode taxonomy, biology and hostparasite relationships. Currently his responsibilities include teaching nematology, taxonomy, biology and nematode interactions. $\mathrm{He}$ is an active member of the Society of Nematologists, the Organisation of Tropical American Nematologists and the European Society of Nematologists (he also served for 4 years as active member of the governing board of this society) and currently is on the editorial board of the International Journal of Nematology and Helminthologia. His research activities have resulted in nine contributions to national and 30 to international meetings, and 95 national journal and 116 international journal articles. He contributed to the $\mathrm{CABI}$ Publishing Crop Protection Compendium and recently co-authored a comprehensive monograph of the plant-parasitic nematode genus Rotylenchus. 


\section{Preface}

It is a pleasure for us, as Series Editors, to introduce the second monograph on plant-parasitic nematodes by Pablo Castillo and Nicola Vovlas, the first being on the genus Rotylenchus. This volume, the sixth in the Nematology Monographs and Perspectives series, follows the same, highly successful pattern as its predecessor and, in dealing with Pratylenchus, a genus of such worldwide economic importance, will be of great assistance to nematologists, agronomists and plant pathologists. This volume covers the morphology and systematics of the genus and provides full descriptions of all 68 species considered to be valid by the authors. All species are illustrated by line drawings and, in some cases, light micrographs. In addition, distribution data and associated hosts are also provided together with a comprehensive bibliography. Dichotomous and tabular keys to the valid species are provided. Management options for these nematodes are discussed in detail and include biological methods as well as rotation strategies, resistant/tolerant varieties and chemical control.

In the Preface to the authors' previous monograph on Rotylenchus, Michel Luc commented: "It is to be hoped that the present work will serve as a model for future monographs on other genera of plant-parasitic nematodes". That hope has now been fulfilled.

David J. Hunt and Roland N. Perry Harpenden, UK March 2007 


\section{Foreword}

Root-lesion nematodes of the genus Pratylenchus are recognised worldwide as one of the major constraints of crops of primary economic importance, including banana, cereals, coffee, corn, legumes, peanut, potato and many fruits. Pratylenchus species rank second only to rootknot and cyst nematodes as having greatest economic impact on crops worldwide. This is not only due to their wide host range, but also to their distribution in almost every cool, temperate and tropical environment. They are migratory endoparasites that cause severe root damage on a wide range of crops whilst feeding primarily in the cortical parenchyma.

The genus Pratylenchus comprises 68 nominal species of worldwide distribution that parasitise a wide variety of plants. Nevertheless, the majority of economic damage to herbaceous, vegetables and fruit crops throughout the world is attributable to a dozen of the most common species, including $P$. brachyurus in corn, cotton, peanut, pineapple, potato and tobacco; $P$. coffeae in coffee, citrus, sugarcane and tea; $P$. goodeyi in banana; $P$. neglectus in cereals and legumes; $P$. penetrans in grasses, forages, fruit trees and strawberries; $P$. pratensis in cereals, grasses, ornamentals and strawberries; $P$. scribneri in potato, soybean and strawberries; $P$. thornei in cereals and legumes; $P$. vulnus in pome and stone fruit trees, ornamentals and roses; and $P$. zeae which parasitises corn, rice, sugarcane and wheat.

The book comprises ten chapters and presents summarised and specialised information on various aspects of the root-lesion nematodes belonging to the genus Pratylenchus. Chapter 1 describes the importance of Pratylenchus species in agricultural crops and their world distribution. Chapter 2 presents general morphology and diagnostic traits of Pratylenchus spp. and their usefulness in taxonomy. This chapter also includes morphometric and cluster analyses to separate groups of species in order to facilitate identification. Chapter 3 analyses the taxonomy and systematic position of Pratylenchus and related genera, including a list of nominal species. Chapter 4 provides complete descriptions and morphometrics of all populations characterised for each species, as well as their world distribution. Chapter 5 includes comprehensive tabular and dichotomous keys for species identification. Whilst recognising the com- 
plexity of creating a system to identify such a large number of species, we are nevertheless confident that, by using both systems, the reader has the necessary information to identify the species of Pratylenchus with which they are dealing. Chapter 6 summarises new diagnostic technologies based on biochemical and molecular analyses, which are becoming increasingly important for practical identifications. Chapter 7 includes numerous aspects of the biology of Pratylenchus spp., life cycle, epidemiology and ecology. Chapter 8 comprises a complete revision of the host-parasite relationships between Pratylenchus spp. and herbaceous and woody plants. Chapter 9 presents the pathogenicity and damage of Pratylenchus spp. to crops, as well as their interactions with beneficial and pathogenic fungi and other nematodes. Finally, Chapter 10 illustrates different management strategies for Pratylenchus species, including crop rotation, host-plant resistance, chemical control, soil solarisation and biological control by means of nematophagous fungi, entomopathogenic nematodes, the hyperparasitic bacterium Pasteuria penetrans and nematicidal plants.

Pablo Castillo and Nicola Vovlas

Córdoba, Spain

November, 2006 


\title{
Acknowledgements
}

Since the major portion of this book was completed at home, we would like to express our deep gratitude and indebtedness to our wives and the rest of our families for the neglect and loss they endured during the preparation of this second book in the last 3 years and for all the support they provided. We know that words are not enough to make up for this loss, but it is the only thing that we can do here and now. Likewise, we thank our colleagues and friends from the Institute of Sustainable Agriculture, Consejo Superior de Investigaciones Científicas (CSIC), Córdoba (Rafael M. Jiménez Díaz, Juan A. Navas Cortés and Blanca B. Landa del Castillo) and the Institute for Plant Protection, Nematology Section, Consiglio Nazionale delle Ricerche (CNR), Bari (Alberto Troccoli and Franco Elia), for their help, suggestions and interest in this book. We also thank Dr R.N. Inserra for his help and Dr Deliang Peng for his contribution to the translation of papers in the Chinese language.

We particularly thank the Series Editors for their great assistance with the English and for editorial suggestions and comments.

Finally, we are grateful to the journals for allowing reproduction of illustrations and to the many nematologists who, through their work on this genus, have contributed to a better knowledge of diagnosis, biology, parasitism, ecology and management of the many species included in the genus Pratylenchus.

\author{
Pablo Castillo ${ }^{1}$ and Nicola Vovlas ${ }^{2}$ \\ ${ }^{1}$ Institute of Sustainable Agriculture, Consejo Superior de \\ Investigaciones Científicas (CSIC), Córdoba, Spain \\ E-mail:aglcascp@uco.es or pcastillo@ias.csic.es \\ ${ }^{2}$ Institute for Plant Protection, Section of Bari \\ Consiglio Nazionale delle Ricerche (CNR), Bari, Italy \\ E-mail:n.vovlas@ba.ipp.cnr.it
}

